\title{
Dylan Thomas’s Deaths and Entrances: A Poetic Culture
}

\author{
S. Bharadwaj ${ }^{1, *}$ \\ ${ }^{1}$ Department of English, Annamalai University, Chidambaram, India \\ *Correspondence: 269, South Second Cross, Mariappanagar, Annamalainagar-608002, Cuddalore District, \\ Tamilnadu, India. Tel: 91-944-398-8633 E-mail: mithrabharath@yahoo.in
}

Received: June 11, 2015

doi:10.5430/wjel.v5n3p15
Accepted: July 27, 2015 Online Published: August 19, 2015

URL: http://dx.doi.org/10.5430/wjel.v5n3p15

\begin{abstract}
From a study of Dylan Thomas's Deaths and Entrances(1946) emerges a distinctive approach to poetry: poetry as a source of inspiration and solace to different strata of humanity. W.H. Auden's system of freedom from personal experience offered in Poems(1928) which was an inspiring ideal of intensity or God's Word to the War poet F.T. Prince emphasizes the mind's need of acquiring identity through suffering and transcendental experience. It is this faith in the possibility of deliverance from the bondage of experience that is almost repudiated in the poems of the other War poets, Roy Fuller, Alan Rook, and Keidrych Rhys. The adverse criticism of Auden's contemporaries and of the War poets on the aesthetic transcendence of Auden and of Thomas as "unpitying, passion-tossed" seared their body and spirit. The consoling assurance to Thomas in such moments of lonely exile and mental crisis as to the poet's task was the thought from A.E. Houseman, and Auden in Eliot alone discovered the meaning of his life and poetry.Thomas's later poetry, being a paradox different from a fanciful construction of single meaning, stands open-ended in its meanings. Hence this paper, adopting a semantic study of Thomas's paradoxical poems, aims at unravelling the meaning of his poetic "culture that is profitable,"consoling and sustaining to fellow-mortals.
\end{abstract}

Keywords: commisseration, skeptical, extinction, pristine, visionary, intensity, oscillate

\section{Introduction}

From a study of Dylan Thomas's poetry published between 1934 and 1946 emerge four approaches to poetry: poetry as a vehicle of pleasurable sensations, poetry as a remedy against ills, as an anchorage affording release from the pressure of actuality, and poetry as a source of inspiration and solace to different strata of humanity. His 18 Poems generates life of joy among the grief-stricken poets of the thirties through the process of death and creation, "the gushers of the sky ... spout to the rod ... divining in a smile the oil of tears," "day light the bone," "the skinning gales unpin ... the winter's robes," "the film of spring is hanging from the lids," "light breaks on secret lots," "blood jumps in the sun," and "above the waste allotments the dawn halts." Thomas breaks out:

Light breaks where no sun shines;

Where no sea runs, the waters of the heart

Push in their tides;

And, broken ghosts with glow-worms in their heads,

The things of light

File through the flesh where no flesh decks the bones. (Poems94)

His early poems kindle sensational and exciting "tips of thought" in the afflicted mind of the poets of the thirties to destroy and create "when logics die."

Thomas's next volume, 25 Poems alchemizes the artistic failures and sufferings, "beginning with doom in the ghost," into artistic success, "the springing marvels," and offers a hope for art songs, "image of images" to Auden's lovers, Cecil Day Lewis, Stephen Spender, and Louis MacNeice. In contrast to Auden’s objective poetics, "my ghost in metal," "my metal phantom," "my man-iron sidle" Thomas, while "forcing forth through the harebell ... my man of 
leaves and bronze root, mortal, unmortal ... in my fusion of rose and male motion," creates "this twin miracle" of art songs and purgation, passion and commisseration. He brings out in the poem "This Bread I Break":

This flesh you break, this blood you let

Make desolation in the vein,

Were oat and grape

Born of the sensual root and sap;

My wine you drink, my bread you snap. (136)

The third book of poems and prose stories, The Map of Love struck "the sinners' dust-tongued bell," liberated the War poets from human bondage of egotistical experience, "the dumb flame," or ignorance and salvaged them with the poet's way of knowledge. There is "storm, snow, and fountain in the weather of fireworks," "grief with drenched book," "the voice of bird on coral prays," "ding dong from the mute turrets," "all love's sinners in sweet cloth" and "a hyleg image." Thomas brings forth:

It is the sinners' dust-tongued bell claps me to churches

When, with his torch and hourglass, like a sulpher priest,

His beast heel cleft in a sandal,

Time marks a black aisle kindle from the brand of ashes,

Grief with dishevelled hands tear out the altar ghost

And a firewind kill the candle. (89)

Commenting on the War poets's love for the poetic culture of Thomas, Day Lewis repeats: "Into the blue we project / Our dreaming shadows”(Collected Poems274 ). W.H. Auden's Poems (1928) being “forlorn” in nature, Thomas's 18 Poems is self-identical, "that our images ... more masterful are, more true."

In Deaths and Entrances Thomas, being faithful to his "immortal friends," his models of moral disinterestedness and poetic culture, inspired the War poets with a hope for poetry:

He'll bathe his raining blood in the male sea

Who strode for your own dead

And wind his globe out of your water thread

And load the throats of shells

With every cry since light

Flashed first across his thunderclapping eyes. (47)

His life, "a winter's ballad” stands as a sanctimonious poetry of inner sanctum of the poets past, future, and the living:

\section{It is a winter's tale}

That the snow blind twilight ferries over the lakes

And floating fields from the farm in the cup of the vales

Gliding windless through the hand folded flakes,

The pale breath of cattle at the stealthy sail. (Poems21)

Thomas's aesthetics identical to that of A.E. Houseman has been relentlessly moral, self-sacrificing and superior to Auden's aesthetic, amoral disinterestedness: "Above the nettles, over the winds, /The man, he does not move, /The man of grave, the lover /That hanged himself for love” (Houseman 33). MacNeice evaluates Thomas's Deaths and Entrances:

We were the past—and doomed because

We were a past that never was;

Yet grant to men that they may climb

This time-bound ladder out of time 
And by our human organs we

Shall thus transcend humanity.(Collected Poems234)

On the contrary, Auden wrote poetry as a mode of conquering and transcending the temporal order and acquiring a direct access to the realm of eternity. Thomas describes Auden's poetry as “a winter's tale”:

And the stars falling cold,

And the smell of hay in the snow, and the far owl

Warning among the folds, and the frozen hold

Flocked with the sheep white smoke of the farm house cowl

In the river wended vales where the tale was told. (Poems )

The chief emphasis in Auden's early phase, especially in Poems (1928), Poems (1930), and Look Stranger! is, however, on the transcendental significance of poetry written for preserving the Passions, the ideological, elite, and metaphysical structure. The War poet F.T. Prince's early poem Poems (1938) vouchsafes for the tale or pilgrimage of Auden as a voyage of suffering and salvation. "This prayer, this hymn, this feckless word ... O Thou my silence, Thou my song ... Thou my meaning, Thou my death” (MacNeice Collected Poems 234 ).

\section{Reviews, Methods and Objectives}

Thomas's Deaths and Entrances “raised him to his full Merlin-height of poetry” (Jones 116). His later poems are "the possible result of a sense of guilt and a desire for atonement...” (Treece 127). Vernon Watkins calls his friend “Dylan” “a Blakean Christian” (237). John Ackerman, appreciating “the greater lucidity” (136), “a notable widening of theme and technique" in Deaths and Entrances, writes that Thomas "makes greater use of Christian ritual and theology” (116). Walford Davies holds that Thomas's “attitude and tone remain richly problematic" though there is less obscurity (59). A great deal of criticism on Deaths and Entrances, as it remains limited to general statements and syntactical elucidations, had not clarified the semantic problems of the readers. His later poem, being a paradox different from a fanciful construction of single meaning, stands open-ended in its meanings. Hence this paper, adopting a semantic study of Thomas's paradoxical poem, aims at unravelling the meaning of his poetic "culture that is profitable," consoling and sustaining to fellow-mortals.

\section{Analysis and Discussion}

Thomas's early poem 18 Poems was written with the knowledge of moral detachment emulated from Thomas Hardy and W.B.Yeats, the knowledge of the possibility of individual human beings attaining to the architectonic intensity and noble spiritual heights, "that listless effort tends ... to grow percipient with advance of days” (Hardy Collected Poems 168), of man's instinctive nature to "labour to be beautiful” (Yeats Collected Poems 64). Thomas tells the fellow-poet his "ripening rule”:

Oh as I was young and easy in the mercy of his means

Time held me green and dying

Though I sang in my chains like the sea.(Poems 55)

This is the final commentary on his identity and his work. In Auden's juvenile poems and Poems(1928), the stress is on "the food and flames of the snow," the power and influence of pain, the rule and energy of Walter de la Mare's poetry, "torn and alone in a farm house in a fold ... fields" to bridge the gulf between man and God, suffering and salvation. To quote the words of Thomas: "Once when the world turned old / On a star of faith pure as the drifting bread... (Poems). In 18 Poems, the task of Thomas aiming at "inner lives of dreams”(HCP 144), "perfection of the life” (YCP 209), “ ... in time alone ... may man, full grown, reach out over the void ... a rapt , creator’s wing” (Day Lewis 274) stands as stark contrast to Auden's poetry directed at"philosophic ...poetic souls” (HCP), "perfection of the work” (YCP), “Time's your condition” interrelated to the order and "architectural masks” of poetry.

Auden's own system of salvation or freedom from personal experience or ignorance offered in Poems which was an inspiring ideal of intensity or God's Word to the War poet Prince's early poems as symbolically particularized in Thomas's readapted popular poem "Fern Hill” emphasizes the mind's need of acquiring identity through suffering and transcendental experience. The parable is at bottom optimistic: it carries the promise that although man is born to suffer, he can also transcend this suffering. Thomas rephrases Prince's mystical joy juxtaposed with the mystique joy 
of the contemporary War poets:

The night above the dingle starry,

Time let me hail and climb

Golden in the heydays of his eyes

And honoured among wagons I was prince of the apple towns.

And once below a time I lordly had the trees and leaves

Trail with daisies and barley

Down the rivers of the windfall light.(54)

It is this faith in the possibility of deliverance from the bondage of experience, "now as I was young and easy under the apple boughs ... about the lilting house and happy as the grass was green...," that is almost repudiated in the poems of the other War poets, Roy Fuller, Alan Rook, and Keidrych Rhys. Emulating the poetic ideal of Thomas, they dismiss what they call the superstitious notion of Auden that the world is the vale of tears, "the trees and leaves ... trail with daisies and barley," and prefer to call it "the rivers of the windfall light" (Poems).

Occasionally as in Poems Auden is disturbed by the "white trades," the question of his contemporary Rex Warner whether the poet serves any useful role in society, "the spit and the black pot in the log bright light ... and the cup and the cut bread in the dancing shade"(Thomas Poems 21), but such conflicts prove momentary. In Poems (1930), the conflict is persistent and pervasive between Warner, Day Lewis, Spender, MacNeice and Auden. However, under the influence of Eliot's ironic technique, "the veiled sky" Auden "wept from the crest of grief " with no care for his contemporaries."Past the statues of the stables and the sky roofed sties / And the duck pond glass and the blinding byres alone"(Poems). Day Lewis in From Feathers to Iron and The Magnetic Mountain, Spender in Twenty Poems, and MacNeice in Blind Fireworks questioned the adequacy of their poetry and attempted to evolve a poetic structure, "the home of prayers ... and fires," a synthesis of Auden's artistic technique and Warner's time spirit, "prayers and fires." The conflicting claims of Auden and Warner, "the cloud of his snow" and "love and rush in the white lairs" threatened a rupture in Day Lewis's poem A Time to Dance, Spender's Poems, and MacNeice’s Poems, “... no sound flowed down the hand folded air.” Thomas recalls:

But only the wind strung

Hunger of birds in the fields of the bread of water, tossed

In high corn and the harvest melting on their tongues,

And his nameless need bound him burning and lost

When cold as snow he should run the wended vales among

The rivers mouthed in night.... (21-22)

The conflict became intenser with the outbreak of the Spanish Civil War in 1936 and the doubt of Day Lewis, Spender, and MacNeice whether the imaginative and intellectual, transcendence and social conscience of Warner and Auden was not fundamentally deceptive and unreal deepened their perplexity and resolute mind. "Never to flourish in the fields of the white seed / Or flower under the time dying flesh astride" (22). MacNeice comments on their love's labours lost:

O pattern of inhuman good,

Hard critic of our thought and blood,

By whose decree there is no zone

Where man can live by men alone,

Unveil Thyself that all may see

Thy fierce impersonality.(MCP234)

The defeated time-conscious poets's search, "the believer lost and the hurled outcast of light," for imaginative release from mortal bondage continued under the influence of the Surrealistic poet Thomas's 18 Poems, "the minstrels" and "the voice of the dust of water from the withered spring." But at certain agonizing moments Auden in Look Stranger! repudiates the Apocalyptic poems of Thomas whom he identified with the visionary poet Warner. Thomas brings out: 
It was hand or sound

In the long ago land that glided the dark door wide

And there outside on the bread of the ground

A she bird rose and rayed like a burning bride

A she bird dawned, and her breast with snow and scarlet downed.

(Poems)

Auden is skeptical as to the poetry of Thomas, "the wizened stream with bells and baying water bounds."

The quick shifts in Auden's contemporaries's divided attitude between the aesthetic of interestedness and disinterestedness, mortality and immortality as evident in the following observation of Thomas reveal the force of the identical inward struggle of Prince dreaming of Auden's art and its permanence:

The sky, the bird, the bride,

The cloud, the need, the planted stars, the joy beyond

The fields of seed and the time dying flesh astride,

The heavens, the heaven, the grave, the burning font.

In the far ago land the door of his death glided wide.... (23)

MacNeice, commenting on the fellow-poets’s divided pursuit of immortal art as “prayer in mid-passage,” explains:

O Thou my monster, Thou my guide,

Be with me where the bluffs divide

Nor let me contemplate return

To where my backward chattels burn

In haunts of friendship and untruth-

The Cities of the Plain of Youth.(MCP)

Auden's tone of the dilemma in New Year Letter, especially in the sonnets, and in For the Time Being, is both mocking and wistful. Thomas remarks:

The dancing perishes

On the white, no longer growing green, and, minstrel dead,

The singing breaks in the snow shoed villages of wishes

That once cut the figures of birds on the deep bread

And over the glazed lakes skated the shapes of fishes.... (Poems)

It is, however, in the allegorical poem "The Sea and the Mirror" that the readers note a harsh, almost dismissal of Prince’s poetry, “the heaven headed ... bird” as a hope for immortality. Thomas sums up "the tale” of Auden’s "pilgrimage as pain":

Flying. The rite is shorn

Of nightingale and centaur dead horse. The springs wither

Back. Lines of age sleep on the stones till trumpeting dawn.

Exultation lies down. Time buries the spring weather

That belled and bounded with the fossil and the dew reborn. (Poems)

Prince’s romanticism, "love enmeshed in his own folly,” "broken years,” "undying fall,” despite "all his fretting ... and gaunt regretting," according to Day Lewis, "the spoilt Junes when a gusty rain ... strums fitful arpeggios on the pane, the dawns when light is denied" could not "sing to a new setting” (269) of Auden who "conquers gravity still” (MCP 233).

It is true that MacNeice qualifies his censure of Prince by drawing a distinction between a lonely dreamer of beauty, the War poet Prince and Auden, the poet of historic sense and architectural beauty:

Thus Here and We, neither of which is what 
The mind and map admit, in perfidy are linked;

This green foam frets away our sense of duty

While we, who watch it blossom and bulge, are not

Spectators in our hearts but murderers of beauty.(MCP 233)

But what may be called purely aesthetic activity of Prince looking for the golden rule receives withering derision from Thomas: "No longer will the vibrations of the sun desire on / Her deepsea pillow where once she married alone, / Her heart all ears and eyes, lips catching the avalanche / Of the golden ghost who ringed with his streams her mercury bone ...” (106). The visionary poets's search for art song, Day Lewis for the golden handshake, Spender for the golden handcuffs, MacNeice for the golden parachute, receives the same treatment. MacNeice himself records:

Yes, it was unbelief. He knew only too well

That circumstances called for sacrifice

But, shivering there, spreadeagled above the town,

His blood began to haggle over the price

History would pay if he were to throw himself down. (235)

On the whole, all of them, the golden girl, "the golden ghost," and the "golden luggage” are running after the golden goose, according to Thomas, "the jealous coursing of the unrivalled blood” (Poems).

And Auden, the true poet is distinguished from a visionary. MacNeice evaluates:

He never made the dive-not while I watched.

High above London, naked in the night

Perched on a board. I peered up through the bars

Made by his fear and mine but it was more than fright

That kept him crucified among the budding stars. (MCP)

Auden, the golden bough, continues his pilgrimage "to hear the golden note" in the church of the Deadsea, the Agape in the church. Thomas comments: "Waking alone in a multitude of loves when morning's light / Surprised in the opening of her nightlong eyes / His golden yesterday asleep upon the iris... (Poems). Auden is, however, ranked below the active doer Thomas dedicated to human service. MacNeice evaluates:

And yet we know he knows what he must do.

There above London where the gargoyles grin

He will dive like a bomber past the broken steeple,

One man wiping out his own original sin

And, like ten million others, dying for the people. (MCP)

Thomas the golden lover of human self, Eros or Cupid, works relentlessly for the golden age of humanity: "And this day's sun leapt up the sky out of her thighs / Was miraculous virginity old as loaves and fishes, / Though the moment of a miracle is unending lightening / And the shipyards of Galilee's footprints hide a navy of doves" (Poems). He believes in the sufficiency of his poetry: "Exiled in us we arouse the soft, / Unclenched, armless, silk and rough love that breaks all rocks" (135). And this is also evident from MacNeice's lines: "And though today is arid ... we know ... that rooted in futurity ... there is a plant of tenderness.” (MCP).

Prince thought that Auden's poetry, viewed as “wailed and nested in the sky-blue wall," “a giant tear for the little known fall," could be a substitute for religion and be the mainstay of a race that had lost faith "when earth grew loud ... in lairs and asylums of the tremendous shout," "a lost wilderness," "a tear for joy in the unearthly flood," "this inhospitable hollow year" and "the drooping of homes ... that did not nurse our bones" (Poems). Auden, identified with "the Saviour" and his poetry of sorrow with the religion of sorrow, "glory to hear ... in the churches of his tears," is believed as the present modernistic Matthew Arnold of past Victorian Age whose critical works "The Study of Poetry," Culture and Anarchy, Literature and Dogma, and God and the Bible assert the value of poetry and literature as an anecdote to the cultural anarchy of his age. In "The Study of Poetry,” Arnold writes:

The future of poetry is immense, because in poetry, where it is worthy of its destinies, our race, as time goes on, will find an ever surer and surer stay. There is not a creed which is not shaken, 
not an accredited dogma which is not shown to be questionable, not a received tradition which does not threaten to dissolve. Our religion has materialized itself in the fact, and now the fact is failing it.... The strongest part of our religion to-day is its unconscious poetry. (63)

In the poem "There was a Saviour," Thomas reconstructs the Arnoldian thinking of Prince:

There was a saviour

Rarer than radium,

Commoner than water, cruller than truth;

Children kept from the sun

Assembled at his tongue

To hear the golden note turn in a groove,

Prisoners of wishes locked their eyes

In jails and studies of his keyless smiles.(Poems)

Prince did not explicitly express such belief, but he did in a sense resurrect Arnold to exploit "a Machiavellian creed." This statement needs qualification for Prince being consistently inconsistent "being adhoc must crumble again" $(M C P)$. His faith in Auden's poetry as religion of suffering and patience, “ ...every tune or crater ... carrying cloud, Death strikes their house" was accompanied by doubts and questionings, "love” and "loss," subjectivity and objectivity. "The windows pour into their heart / And the doors burn in their brain" (Poems). The doubts and oscillations enlarge and enrich the texture of his poetry, MacNeice observes:

Though loves languish and sour

Fruit puts the teeth on edge,

Though the ragged nests are empty of song

In the barbed and blistered hedge....(MCP)

Prince's "winch of will was busy ... behind his eyes," his "dizzy ways led zigzag through the mirk," "so deprecatingly he blew a nought ... in smoke and threw the stub into the purring gate" and "his colonizing fate through Africas of thought” (MCP 233) also underline his inability to reach forward to a definitive pattern of thought:

He always broke off so, abrupt but shy

In knowledge of his mission, veered and tacked

To his own breezes—-till as a variation

His explanation cracked and threw the words awry.... (MCP)

Towards the end of Poems Prince is seen confronted with a conflict between artistic conscience and social conscience, between the individual talent and the poetic tradition past and present, Auden and Wilfred Owen. He justifies his existence as an individual in the society, while bidding goodbye to Auden's art of power and prayer and to Owen's half-rhythm of poetic truth and pity of war, writing poems with the Wordsworthian theory of poetry as "powerful emotions recollected in tranquility" (180) and leaving his identity, his accentuation as an aesthetic poet to the future. His main accent is on creation of beauty pleasing to both ears and eyes. Thomas reconstructs Prince's intentions:

In my craft or sullen art

Exercised in the still night

When only the moon rages

And the lovers lie abed

With all their griefs in their arms,

I labour by singing light

Not for ambition or bread

Or the strut and trade of charms 
On the ivory stages

But for the common wages

Of their most secret heart.(Poems 82)

Prince’s desire to work “freely” from Owen’s conscience of war misery, "the lash and lightning ...cautery of rage of Owen” or from the influence of Auden's "blind numb grinding severance ... of floe from floe” (DCP 260), Day Lewis perceives, signals his dreaming to be an immortal aesthetic poet, a "merciless god” which, in turn, mocks his "failures" to make himself a true poet. MacNeice describes his conflict: "Conditioned to think freely, how can we / Patch up our broken hearts and modes of thought in plaster / And glorify in chromium-plated stories... (MCP 232).

Prince's "slow fissure" from "the tight-lipped technocratic Conquistadores..." the poetic process of Auden and Owen reminds Thomas of the severance of Day Lewis, Spender, and MacNeice from Auden's "sullen art” which is the main motif of Thomas's sonnet sequence, “Altarwise by Owl-Light” acclaimed as his own accentuation, his "heyday's afterglow." Thomas explains that the dominant note of the interrelated art songs showing the direct bearing of art on the human situation and co-existence is not his egotistical sublime but self-commisseration and self-sacrifice voiced for the realistic, socially conscious poets of the thirties:

Not for the proud man apart

From the raging moon I write

On these spindrift pages

Not for the towering dead

With their nightingales and psalms

But for the lovers, their arms

Round the griefs of the ages,

Who pay no praise or wages

Nor heed my craft or art. (Poems)

Thomas's artistic, cynical concern has not evoked any sentimental pity or a melodrama, "not with mingling tears ... nor one long backward look of woe” but a mellifluous melodic sound "towards a sinking trust” (DCP). MacNeice opines that Thomas stoops to conquer and vindicates his existence as an artist of pity by losing his identity and by adopting more adaptability, his talent on a par with the transcendental Auden:

The individual has died before; Catullus

Went down young, gave place to those who were born old

And more adaptable and were not even jealous

Of his wild life and lyrics. Though our songs

Were not so warm as his, our fate is no less cold. (232)

Thomas's art of pity, his poetic culture though not “so warm” as Owen’s or not so “cold,” “tight-tipped,” “sullen” as Auden's, is seen more warm or "no less cold” as his poetic ancestors, Hardy, Yeats, and Houseman or not "ready under new names to exploit or be exploited” (MCP).

The conflict between artistic conscience and social conscience which is the focal point in Auden's "The Sea and the Mirror,” Day Lewis’s Poems 1943-47, Spender's Ruins and Visions, and MacNeice's Springboard is related to other, equally disturbing questions discussed in Thomas's poem "Ceremony after a Fire Raid.” This poem throws light upon the central concern of the ambiguous poem “A Refusal to Mourn the Death of, by Fire, of a Child in London”:

\section{Myselves}

The grievers

Grieve

Among the street burned to tireless death

A child of a few hours

With its kneading mouth

Charred on the black breast of the grave 
The mother dug, and its arms full of fires. (Poems 44)

The topography is like the Second World War corpse. The climate is severer and sharp and everything is being seen as dead, "afflicted," and "fervourless." Here the situation and the experience involving the changed attitude of the poets of the thirties, the erstwhile faithful friends of the Surrealistic poet Thomas, "Myselves" becoming socially conscious poets of pity, " the grievers ... grieve," are more complex. The mind of Thomas is oppressed also by thoughts of mutability in Day Lewis's Poems 1943-47, Spender's Ruins and Visions and Poems of Dedication, MacNeice's The Spring Board and of Auden's faith in the Christian idea of human redemption in For the Time Being. Thomas persuades:

\section{Begin \\ With singing}

Sing

Darkness kindled back into beginning

When the caught tongue nodded blind,

A star was broken

Into the centuries of the child

Myselves grieve now, and miracles cannot atone. (Poems)

The poem "Ceremony after a Fire-Raid" is about Thomas's optimism and human possibilities for progressive enlightenment in the world rather than about a religious certainty that comes right in the earnest.

The War poet Prince and Auden's contemporaries Day Lewis, Spender, and MacNeice moved from one resolution to another, and Thomas's poems, "Once Below Time," "When I Woke," "Among Those Killed in the Dawn Raid was a Man Aged a Hundred," and "Lie Still, Sleep Becalmed," are records of their troubled consciousness. The difficulty in arriving at a system was enhanced by their theory of knowledge. Day Lewis reports:

Their doubles draw the willows, a brown mare

Drinks her reflection. There's no margin where

Substance leaves off, the illusory begins. (247)

The dilemma in Prince's mind is this: Should a poet convey merely his personal experiences, or should he seek to comprehend and express the world outside of his immediate experience? After rejecting his immortal model and the Saviour Auden, "to live in his future ... is to live surely ... in his own death," he chooses the philosophic poetry of the Roman poet Catullus as his ideal and endures "the embrace of the present ... but yearn for a being beyond us" (DCP 274). Thomas explains: "The morning is flying on the wings of his age /And a hundred storks perch on the sun's right hand” (Poems 30). The other War poets Fuller, Rook, and Rhys who had already resolved to perpetuate the poetic ideal of Thomas found that their attempt to cast ended as undercast. Their dilemma was: Is poetry merely a purveyor of sensations, or is it at a higher level, an allegory integrating sensation and thought? Day Lewis describes their predicament:

$$
\begin{aligned}
& \text { Tonight, as fliers stranded, } \\
& \text { On a mountain, the battery fading, we tap out } \\
& \text { Into a snow-capped void our weakening }
\end{aligned}
$$

Vocations and desires.(274)

Finding that Prince had "undone" his god, Auden, the War poets adapted themselves to be free individuals to exploit the philosophic poetry of the First World War poet Edmund Blunden. "And when the salt sheet broke in a storm of singing / the voices of all the drowned swam on the wind" (Poems 93).

MacNeice in Springboard debatesif the aim of the poet is to attain truth, what is the nature of this truth? He finds answer in the philosophic poetry of Emily Bronte, "his grey-haired heart" (Thomas) and finds "upclimbing from afar ... over" the poetry of human sorrow of Thomas, his "chaste ... disenchanted and death rebuking star" (279). In Ruins and Visions, Spender's conflict is between Owen's survey of human reality and Thomas's exploration of the realms of consciousness beyond the reality. He "woke" to the pacifism of Owen's half-rhythm. "I drew the white sheet over the islands / And the coins on my eyelids sang like shells" (Thomas 147). In Poems 1943-47 Day Lewis questions the value of the power of Thomas's poetry that ultimately leads to a severance from the more 
substantial work of human endeavours and affections though he continued to remember Thomas for his "compassion," "generous glow" in the "humbled creation” of the art songs "Altarwise by Owl-Light." Thomas recalls;

Never never oh never to regret the bugle I wore

On my cleaving arm as I blasted in a wave.

Now shown and mostly bare I would lie down,

Lie down, lie down and live

As quiet as a bone.(108)

Day Lewis abides by the philosophic poems of the “warmer-hearted and brisker-eyed” Paul Valery.

Auden in "The Sea and the Mirror" doubts if poetry be a means of exploring truth-whatever the frontiers of truth may be-how far can it compete with the faculty of reason? He derives hope for poetry and divination in the God-centric lyrics of de la Mare whom he breathed as his rule and energy for his juvenile verses and Poems (1928) and in the Auden-centric early poems of Philip Larkin in contrast with the early lyrics of the skeptical Ted Hughes. "And the golden pavements laid in requiems, / Into the bread in a wheatfield of flames, / Into the wine burning like brandy" (Thomas 45). The same point of Auden's "meaning” and immortality is the focal point of discussion in Thomas’s poem “Vision and Prayer” which sums up:

Who

\author{
Are you \\ Who is born \\ In the next room \\ So loud to my own \\ That I can hear the womb \\ Opening and the dark run \\ Over the ghost and the dropped son \\ Behind the wall thin as a wren's bone? \\ In the birth bloody room unknown \\ To the burn and turn of time \\ And the heart print of man \\ Bows no baptism \\ But dark alone \\ Blessing on \\ The wild \\ Child. (Poems 143)
}

The end of the poem For the Time Being marks a ray of hope for Auden's poetry and future, a life for his “meaning” and his "death," "the roots of Atlantis flowers" $(D C P)$.

The end of the poem "Ceremony After a Fire Raid" projects the depressed condition of Thomas. Can the time-conscious philosophic poetry of all those who had faulted his disinterestedness and turned away from him attain an integrated, unified vision of reality? Thomas analyses:

\title{
Crying \\ Your crying
}

Cry,

Child beyond cockcrow, by the fire-dwarfed

Street we chant the flying sea

In the body bereft. 
Love is the last light spoken. Oh

Seed of sons in the loin of the black husk left.(Poems)

At the end of the poem "The Sea and the Mirror" the depressed Auden, "that immortal hospital" makes "one more move to soothe the cureless" left-lenient poets, "the multitude's sultry tear," 'my arising prodigal ... sun" and the War poet Prince "the barbed and shooting sea," "Gabriel and radiant shrubbery" to assume "an army" to defeat Thomas. He implores to the poets of pity to pity him:

Spare me a humiliation,

To your faults be true;

I can sing as you reply.... (ACP)

Day Lewis, Spender, and MacNeice oscillate between buoyancy and depression, a sense of power and an awareness of limitations: poetry appears to them as elegance that towers above Auden and they compare themselves with fascination; and yet Auden's elegant art seems mortal compared with Thomas's paradoxical art. Thomas's descriptions of Prince's poems, metaphorically used, "the morning grows joyful ... out of the woebegone pyre," "the infants of pure fire," thus bring out appositely the tension in his mind and his conflicting emotions regarding the worth of his own creative endeavour, the dreadfulness of which, again, both fascinates and unnerves him despite Auden's supplication, "I will sing if you will cry.” Auden wrings an unexpected tenderness on the eve of his journey to the blessed future:

Never hope to say farewell,

For our lethargy is such

Heaven's kindness cannot touch

Nor earth's frankly brutal drum.... (ACP)

He seeks communion with the fellow poets to be the holy of holies, but he is doubtful about hope for his poetry and future as the fellow-poets are persistently dreadful of his impersonality.

Two other adaptations from the philosophic tradition reinforced Auden's speculations regarding the truth of human existence and the problem of pain. He found in Kierkegaard's philosophy a convincing solution to the problem of suffering, guilt and anxiety in man's life. In his perceptive "Introduction" to the volume of selections from Kierkegaard, Auden states how the great thinker reacted to human suffering:

As long as your suffering makes you defiant or despairing, as long asyou identify your suffering with yourself as an existing individual, and are defiantly or despairingly the exception, you are not a Christian. (5)

In fact, the middle phase of Auden's poetic carrier is “a leap into the void," an abject surrender to God in which man has no foothold, and his faith alone can lead him into a new world beyond all rational thought. "The more the suffering the more the religious existence ..." (256) wrote Kierkegaard and his belief that to be a Christian one must allow oneself to remain a victim of despair had a touching appeal to Auden. Life is absurd precisely because, though God exists, men guided by sense perceptions cannot know Him. "An unbridgeable abyss," writes Justin Replogle, "separates man from God. By nature limited to temporal experience ... men can never leap across to the timeless, multi-dimensioned existence on the other side" (53). Thus, God, in a sense, is predetermined existential necessity. Since only by submitting to God's design can men be free, human freedom is synonymous with religious faith. Auden read in de la Mare's poetry and in the miseries of his life the strange working of destiny; the mystery that is only grasped by one who has transcended this temporal plane:

\section{That song and sugar and fire, Courage and come-hither eyes}

Have a genius for taking pains. (ACP 311)

In Come Hither, de la Mare sings: "If to the heavens you lift your eyes / When Winter reins o'er our Northern skies, / And snow-cloud none the zenith mars...” (761).

Thomas's situation and concern are very much unlike Auden's when "the partnership” with the Lefties and the War poets is "dissolved with all his unanswered wishes and unwashed days." He was stone-cold for the first time, "fire and ice within me fight ...beneath the suffocating night" (Houseman 49).Thomas sums up in "Ballad of the Long-legged Bait”:

We stand alone in the door of his home, 
With his long-legged heart in his hand.(39)

But in both Auden and Thomas the readers can mark an oppressive consciousness of reality. Auden expresses towards the end of his confessional poem "The Sea and the Mirror":

Both of us know why,

Can, alas, foretold,

When our falsehoods are divided,

What we shall become,

One evaporating sigh. (ACP 341)

The identification of the poets of the thirties, Day Lewis, Spender, and MacNeice and the War poets with the empirical philosophic tradition, "their turning and burning," reaches a deeper level of perception when Thomas reflects on human misery, injustice or inconstancy:

With men and women and waterfalls

Trees cool and dry in the whirlpool of ships

And stunned and still on the green, laid veil

Sand with legends in its virgin laps.... (38)

Several critics, including Watkins, find in Thomas's later poems a deeply religious sensibility that is fundamentally "religious and Christian" (61). AneirinTalfan Davies writes that in Deaths and Entrances Thomas "moved very far towards" Christian orthodoxy (39). Karl Shapiro remarks that Thomas "believed in God and Christ" (104). V.S. Pritchett holds that Thomas's "inner life of the Puritan was not only filled with dramas of power and guilt but these were exotically coloured by his reading of the Bible" (103). It may be worthwhile to repeat here Ackerman's documentation of the Biblical echoes in Thomas's poems shows a not inconsiderable acquaintance with both the Old Testament and the New. He affirms that "Thomas's later poems abound in instances of Christian thought and symbol..." (120). However, Thomas's indifference to Christian doctrines and his hostility to the Church are evident from the beginning, and the poems, 18 Poems and Deaths and Entrances record his reactions.Watkins with whom Thomas came to be acquainted in1935 writes of Thomas as "the extravagant hero of night, his iconoclastic frown" (CV 173) and remembers of his "christening":

If I look deeply there, I see time fade

And light grow perfect, dark; and darkness shine.

Again I see the curve her body made,

Bearing you like a pitcher doomed to wine. (MV 369)

The influence of Hardy, Yeats, and Houseman, their negative example of fusion of Utilitarianism and Puritanism helped to deepen this skepticism. There is "a limited pantheism — an intense and terrible vision of the world as subject to the laws of diminishing returns" (411) according to Derek Stanford.

In Invitation and Warning, Henry Treece perceives that in Deaths and Entrances Thomas, having taken upon himself the pattern of Christian suffering and the form of man in Jesus Christ which he rephrases in the poem "Love in the Asylum" as "... taken by light in her arms at long and dear last," finds a remedy for earlier skepticism, "the deluding light" in 18 Poems, sustenance, consolation and faith, an asylum in the Christian love and breaths in all he sings a Christian spirit:

One day at dawn

Upon their nags

Twelve tinkers from the knuckles of the dogs,

To bear the black cock company.( $C V$ 242)

But Norman McCaig's Far Cry! discounts the report of Treece. However, Watkins's accounts collected from Thomas's allegorical story "The Adventures of an Artist as a Dog” and sang in Ballad of Mari Lwyd and The Lamp and the Veil which Thomas images in the poems "The Hunchback in the Park," "Into Her Dying Down Head," "Paper and Sticks" and "Unluckily for a Death" have a much greater degree of authenticity. What Thomas has pronounced as his skepticism about Christian idea of suffering and salvation in his early poem 18 Poems remains 
unchanged and intact in his poetry published between 1934 and 1946. In the early poem "When, Running Like a Grave” Thomas conveys implicitly:

When, like a running grave, time tracks you down,

Your calm and cuddled is a scythe of hairs,

Love in her gear is slowly through the house,

Up naked stairs, a turtle in a hearse,

Hauled to the dome.... (149)

He was much too honest to subscribe to a faith, the "ruthless" attitude of "the destroyers," that he could not accept from his heart. Thomas explains explicitly in Deaths and Entrances:

Like the park birds he came early

Like the water he sat down

And Mister they called Hey mister

The truant boys from the town

Running when he had heard them clearly

On out of sound.(28)

Thomas's response to the mystery of existence, at its deepest and most intense, is almost akin to religious awe, and yet his rejection of Christianity was unequivocal. His early poem "Our Eunuch Dreams" carries anti-Christian sentiment as he has "faith" in the life of "this ... world," in the archetypal world of Hardy:

For we shall be a shouter like the cock,

Blowing the old dead back; our shots shall smack

The image from the plates;

And we shall be fit fellows for a life,

And who remains shall flower as they love,

Praise to our faring hearts. (110-11)

His anti-clerical sentiment is conveyed in the poem "Especially when the October Wind":

Especially when the October wind

With frosty fingers punishes my hair,

Caught by the crabbing sun I walk on fire

And cast a shadow crab upon the land,

By the sea's side, hearing the noise of birds,

Hearing the raven cough in winter sticks,

My busy heart who shudders as she talks

Sheds the syllabic blood and drains her words. (53)

In Treece's view, Thomas's later poem Deaths and Entrances that revives the Christian faith of 18 Poems shows that his mind was gradually working itself round to the more healthy tone of a Disciple of Christ. "Pain rain over the dwindling harbour / And over the sea wet church the size of a snail.” Thomas remembers Treece's Invitation and Warning:

This I know from the native

Tongue of your translating eyes. The young stars told me,

Hurling into beginning like Christ the child.

Lucklessly she must lie patient

And the vaulting bird be still. (Poems 142) 
Both 18 Poems and Deaths and Entrances demonstrate that Thomas's skepticism prevented the genuine acceptance of any religious creed. "O my true love, hold me, / In your every inch and glance is the globe of genesis spun, / And the living earth your sons” (Poems). So anything like Auden's deathbed conversion is utterly foreign to Thomas's nature. Thomas speaks of the continuous presence of skepticism in his poetry:

All night in the unmade park

After the railings and shrubberies

The birds the grass the trees the lake

And the wild boys innocent as strawberries

Had followed the hunchback

To his kennel in the dark.(129)

Treece's reading of 18 Poems and Deaths and Entrances are evidently misleading according to Thomas. An adaptation from Houseman is highly relevant to the context involving the relentless pursuit of a poetic culture:

Westward on the high-hilled plains

Where for me the world began,

Still, I think, in newer veins

Frets the changeless blood of man.(85)

Thomas's watching "the living meet ... and the moving pageant file," the "warm and breathing through the street" and his crying to dream again evokes the memory of Houseman:

If the hearts of hate and lust

In the house of flesh are strong,

Let me mind the house of dust

Where my sojourn shall be long.(88)

Thomas's rejection of Christian theology had, however, a deeper reason, and this is clearly brought out in his observation in "Unluckily for a Death" included in Deaths and Entrances. His 18 Poems, dedicated forever to the sound voices of Hardy and Yeats, dismisses the superstitious notion that life is the parable of self-extinction, "the winds of love broken wide ...to the wind the choir and cloister ... of the wintry nunnery of the order of lust" and prefers to call it "the clay cold mouth," "the fire ... branded forehead," and "the sun strokes of summer." He confesses: "Unluckily for a death / Waiting with phoenix under / The pyre yet to be lighted of my sins and days..." (141). In the poem "Departure," Hardy "dubious of the cause" of the architectural religion "the far farewell music," "the gray sea” speaks for the individual cause, "the bearing brine," "each significant red smoke-shaft pales":

Keen sense of severance everywhere prevails,

Which shapes the late long tramp of mounting men

To seeming words that ask and ask again....(76)

Here it is pertinent to recall T.E.Hulme's celebrated definition of romanticism as a "split religion" (95) as faith in man's creative and spiritual potential and Hardy also sings in "Tess's Lament”: "To claim my nook, to need my knell, / Time for them to stand and tell / Of my day's work as done" (HCP 158).Christianity rests on the two basic assumptions that man is a fallen creature, and that he can achieve redemption only through grace, the assumptions are fundamentally opposed to the romantic belief that the human mind is "an infinite reservoir of possibilities" (Hulme 116). In 18 Poems, Thomas never shares the Christian horror of sin, "the dark our folly ... cut to the still star in the order of the quick," "the ceremony of souls" but "loving" his "holy lucky body," Yeats. He emulated the poetic culture of Yeats's "deep considering mind ... into the labyrinth of another's being," (YCP 166) to "take our greatness with our bitterness" (169) "to exalt a lonely mind ... befitting emblems of adversity" (170) and "hurried through the smooth and rough ... and through the fertile and waste ... protecting, till the danger past" (180) and demonstrated not only his artistic coherence but also his "human love” and human co-existence. Auden's idea of aesthetic transcendence, his musical structure "communion between suns" had for him a different significance."Never shall my self chant / About the saint in shades while the endless breviary / Turns of your prayed flesh, nor shall I shoo the bird below me...” (Poems). 


\section{Findings and Interpretations}

The inability of the War poets in attaining the intensity of Thomas and the reaction of the poets of the thirties to Thomas's moral disinterestedness, his refusal to be a war poet of pity, "the steady ... pulsing of Orpheus' song ... though lightwards led he ... grew faint in her" (DCP 267), the charge of inconsistency on his part and his "fierce impersonality" stirred him to the depth and the lines from de la Mare irresistibly come in to describe his state of mind:

\section{But when Midsummer Even in man's sleep-drowsed hours \\ Refreshes for daybreak its dew-bright flowers, \\ Though three of these Night Lights aloft remain.... (Complete Poems)}

The adverse criticism on Thomas's poetry as "unpitying, passion-tossed," as his poetry is void of pity and magnanimity with which his 18 Poems is gifted, seared his body and spirit. Day Lewis renders: "He felt the cord parting, / The death-wound smarting: / He turned his head but to glimpse the ghost of her" $(D C P)$.

The withering cry of his erstwhile friends, "thou shalt be nothing," "tombless, with no remembrance" is almost a prayer for deliverance from the arid desert of his disinterestedness. Thomas repeats:

And prophets loud on the burned dunes;

Insects and valleys hold her thighs hard,

Times and places grip her breast bone,

She is breaking with seasons and clouds.... (38)

He recalls his moments of lonely suffering towards the end of his weary journey when fellow-poets's seeming heartlessness and flirtation almost consumed him. "The rod bends low, divining land, / And through the sundered water crawls" (Poems). The Hardy-image contrasting the persistent pursuit of Thomas and the time-conscious poets takes on a special poignancy. Hardy portrays the archetypal poet's "travel-tarnished feet":

From day-dawn until eve he fares

Along the wintry way;

From day-drawn until eve repairs

Unto her mound to pray.(159)

In the poem "Holy Spring" Thomas, while recalling the bitter experience of being banished by his fellow-poets, cries altering the past tense into the present: "I climb to greet the war in which I have no heart but only / That one dark I owe my light... (Poems 63). He always remembers Houseman in moments of lonely exile, in joy and in sorrow. Echoes from Last Poems steal into some of the reflective passages in Deaths and Entrances. In "Holy Spring," Thomas speaks of the horrid morbidity of his temperament. "And I am struck as lonely as a holy marker by the sun" (Poems). The consoling assurance in such mental crisis is the thought from Houseman's poem "The Day of Battle" that life itself is illusory, and in Houseman's vision of the dissolving fabric of the pageant, Thomas finds a dramatic rendering of his own mood. Houseman cries:

"Therefore, though the best is bad,

Stand and do the best, my lad;

Stand and fight and see your slain,

And take the bullet in your brain.” (59)

Houseman offers Thomas parallels, or verbal equivalents for any mood or situation.

Another source of solace and sustenance for Thomas was his friend, “... confessor and wiser mirror but there is none ... to glow after the god stoning night" (Poems), Treece whose Black Seasons (1946) is "the revenant” of Thomas in rack and ruin. Day Lewis explains the occasion of Treece's poem:

Out of the famous canyon

Deeper than sleep,

From the nerveless tarn of oblivion

She climbed. Dark was the slope, 
And her companion

Gave not one love-glance back to brighten it.(DCP 266)

In Treece's language, Thomas finds a dramatic rendering of his own experience which he narrates in his poem "Ballad of the Long-legged Bait." The parallelism and contrast give it both intensity and a relative impersonality. Day Lewis describes the "astonishment" of Thomas for his "banishment," for his being faulted and stonewalled:

What strand of his love was the weak one,

Or how it befell

That a song which could melt the Dark one,

Death's granite lord, with its spell

Saved not his meek one,

Moved not his meek one to step from the last of her

Terrors, no man may tell. (DCP)

For Thomas, this means a release from immediate experience and also a heightening of his experience, "the holy spring” for "a holy marker." He remarks:

Coil from the thoroughfares of her hair

And terribly lead him home alive

Lead her prodigal home to his terror,

The furious ox-killing house of love.(Poems)

Verbal echoes from Auden's metaphysical poems, "under the floating villages," do not have this figurative and associative richness excepting the poems of Hardy and Yeats, "the moon-chained and water-wound ...metropolis of fishes.” The readers hear Thomas's voice changing in a quick shift into Houseman's:

Wake not for the world-heard thunder,

Nor the chimes that earthquakes toll;

Stars may plot in heaven with planet,

Lightning rive the rock of granite,

Tempest tread the oakwood under,

Fear not you for flesh or soul;

Marching, fighting, victory past,

Stretch your limbs in peace at last. (84)

\section{Conclusion}

The moral disinterestedness of Thomas's poetry, his "paper" evokes the cultural archetype of Hardy, Yeats, and Houseman, "fermenting rivers ... intricacies of gloom and glint and ducats of dream and great doubloons of ... ceremony" to smooth down the human suffering. Whereas the amoral aesthetics of Auden, his "stick" seeks the support of religion and philosophy, "a cairn of stones, the shadow and sheen of a moleskin mountain" and "a litter of chronicles and bones" (MCP 224) to remedy the human sickness.Thomas recalls:

Past lake and rockery

Laughing when he shook his paper

Hunchbacked in mockery

Through the loud zoo of the willow groves

Dodging the park keeper

With his stick that picked up leaves. (Poems)

MacNeice evaluates that the poetic culture of Thomas can be adjudged as "Perdita," a symbolic agent of transition from sin and death to grace, renewal and regeneration of life in Shakespeare's The Winter's Tale. He felicitates: 
The glamour of the end attic, the smell of old

Leather trunks-Perdita, where have you been

Hiding all these years? Somewhere or other a green

Flag is waving under an iron vault

And a brass bell is the herald of green country

And the wind is in the wires and the broom is gold. (210)

The historic sense of Auden, his architectural structure of Power, State and Ideologies, "the bones ... of strange weather," "adumberration of unknown glory," "shadow of a passing bird" "the feet of Saint Francis" and "the hazel rod bent" are compared to "the dowser." While Auden's pursuit of truth anticipates the historic Hebrewic tradition and its gnawing desire for more suffering, Thomas's search for a system of values foreshadows the Hellenic tradition and its adventurous love for "archetypal sin." MacNeice, indicating the direction of poetic culture and its implicit values that "a city that is built on mud ... a culture that is profitable" (MCP), pays homage to Thomas's archetypal, pagan culture that wrecks Auden's "equipoise":

A smell of hay like peace in the dark stable-

Not peace however but a sword

To cut the Gordian knot of logical self-interest,

The fool-proof golden cord;

For Christ walked in where no philosopher treads

But armed with more than folly,

Making the smooth place rough and the knocking the heads

Of Church and State together.(164)

So the poetic culture of Hardy, Yeats, and Houseman that "inspired" Thomas to indite poetry of "inner themes and inner poetries" (HCP 140) to blend "pulsing life with lives long done ... till Time seemed fiction, Past and Present one" (89) "to win ecstatic heights in thought and rhyme" $(Y C P)$ and to learn "the road one treads to labour ... will lead one home to rest ... and that will be the best" (Houseman 89) is laid "safe" and consecrated in his poetry "to endless time.” Thomas's architectonic, poetic culture has always been better placed than all the architectural culture that Auden "had raised for me ... in swift perspective Europe's history" in which "her act flashed home ... the power, the pride, the reach of perished Rome" (HCP).

\section{References}

Ackerman, John. (1964). Dylan Thomas: His Life and Work. London: Macmillan.

Arnold, Matthew. (1978). The Study of Poetry. In S. Ramaswami and V.S. Sethuraman (Eds.), The English Critical Tradition: An Anthology of English Literary Criticism Vol.2. Madras: Macmillan.

Auden, W.H. (1936). Look Stranger! London: Faber.

---. (1940). Another Time. London: Faber.

---. (1976). Collected Poems. Mendelson, Ed. London: Faber.

---. (1977). The English Auden:Poems, Essays and Dramatic Writings 1927-1939. Mendelson. London: Faber.

---, ed. (1952). The Living Thoughts of Kierkegaard. Newyork: David Mckay.

Bloom, Harold. (1998). Poetic Origins and the Final Phases. In David Lodge (Ed.), Modern Criticism and Theory: A Reader. New Delhi: Pearson.

Davies, AneirinTalfan. (1964). Dylan: Druid of the Broken Body. London: Dent.

Davies, Walford. (2003). Dylan Thomas. New Delhi: Viva Books.

Day Lewis, Cecil. (1954). Collected Poems 1929-1954. London: Hogarth-Cape.

de la Mare, Walter. (1969). The Complete Poems. London: Faber.

Eliot, T. S. (1978). Tradition and the Individual Talent. In S. Ramaswami and V.S.Sethuraman (Eds.), The English 
Critical Tradition: An Anthology of English Literary Criticism, Vol.2. Madras: Macmillan.

Houseman, A.E. (2004). Poems. London: Hunter.

Hulme, T.E. (1972). Romanticism and Classicism. In David Lodge(Ed.), 20 th Century Literary Criticism: A Reader. London: Longman.

Jones, Gwyn. (1954). Welsh Dylan. Adelphi, 30(2), 108-17.

Kierkegaard, Soren. (1954). Concluding Unscientific Postcript. In David F. Swenson(Ed.), Walter Lowric. Newyork: Doubleday Anchor Books.

MacNeice, Louis. (1949). Collected Poems 1925-1948. London: Faber.

Pritchett, V.S. (1957). The English Puritan. New Statesman and Nation, Liii (1350), Jan. 26.

Replogle, Justin. (1969). Auden's Poetry. London: Methuen.

Shapiro, Karl. (1955). Dylan Thomas. Poetry, 87(2), 100-110.

Shires, M.Linda. (1985). British Poetry of the Second World War. London: Macmillan.

Spender, Stephen. (1942). Ruins and Visions. London: Faber.

Stanford, Derek. (1964). Dylan Thomas: A Literary Post-Mortem. Queen's Quarterly, LXXI(Autumn), 405-418.

Thomas, Dylan. (2004). Poems. London: Hunter.

Treece, Henry. (1949). Dylan Thomas: “Dog Among the Fairies.” London: Drummond.

Watkins, Vernon. (1961). Swansea. Texas Quarterly, IV (Winter), 59-64.

Wordsworth, William. (1962). Preface to Lyrical Ballads. Ed. D.J. Enright and Ernst de Chickera. English Critical Texts: 16 th Century to 20 th Century. London: Oxford UP.

Yeats.W.B. (2004). Collected Poems. London: Wordsworth. 